\title{
Evaluation of the Metal Content and Bacteriological Parameters of Selected Borehole Water Sources in Abakaliki, Nigeria
}

Iroha Chidinma', Iroha Ifeanyichukwu², Nwakaeze Emmanuel ${ }^{2}, \mathrm{Ajah} \mathrm{Monique}^{3}$ and Ejikeugwu Chika ${ }^{2 *}$

${ }^{1}$ Department of Pharmacy, Federal Teaching Hospital, Abakaliki, Ebonyi State, Nigeria

${ }^{2}$ Department of Applied Microbiology, Ebonyi State University, Abakaliki, Ebonyi State, Nigeria

${ }^{3}$ Cancer Screening Unit, Well Women Center, Federal Teaching Hospital, Abakaliki, Ebonyi State, Nigeria

\begin{abstract}
The quality of potable water is affected by several natural and human activities including but not limited to pollution, natural disasters, climate change, urbanization and mining. Poor water quality adversely affects human health, and it is important to periodically be on the lookout for possible water contamination in our environment. This study investigated the metal content and bacteriological profiles of selected borehole water sources in Abakaliki, Nigeria. A total of 25 borehole water samples of $250 \mathrm{ml}$ each were aseptically collected from selected borehole points (designated as Site A-E) in Abakaliki metropolis, Ebonyi State, Nigeria using pre-sterilized plastic containers; and each of the samples was were bacteriologically analyzed on selective culture media for the isolation and identification of bacteria that are of public health importance using standard microbiology identification techniques. The presence of trace metals was chemically determined in the borehole water samples using the atomic absorption spectrophotometer (AAS) [AA-7000]. The highest bacterial count in this study was $2.4 \times 10^{4} \mathrm{cfu} / \mathrm{ml}$ while the least bacteria count was $1.0 \times 10^{4} \mathrm{cfu} / \mathrm{ml}$. The suspected bacterial organisms isolated and identified from the respective borehole water samples were Escherichia coli, Klebsiella species, Staphylococcus aureus and Pseudomonas aeruginosa. The metal content analysis using AAS showed that some of the borehole water samples contain some trace metals such as zinc $(\mathrm{Zn})$, iron $(\mathrm{Fe})$ and manganese $(\mathrm{Mn})$. Aluminium $(\mathrm{Al})$ and lead $(\mathrm{Pb})$ were not detected in the borehole water samples analyzed in this study; and the trace metals detected were found to be within the accepted limit of trace metals for drinking water as specified by Standard Organization of Nigeria (SON) and World Health Organization (WHO). This study has presumptively reported the presence of some bacterial organisms of public health importance and some trace metals in selected borehole water samples in Abakaliki, Nigeria. The area under study is known for its high deposit of mineral resources especially lead and limestone; however, lead was not detected in the water sample and this shows that there was no infiltration of this metal from the mining site to the water sources in the region. Also, the proliferation of mining sites and their unregulated activities could also be responsible for the presence of some of these metals in the environment at concentrations that are unsafe for human use. Unsafe drinking water portends significant risk to public health over a lifetime of consumption. It is therefore important for the authorities to periodically screen water meant for human use and public consumption for the presence of potential physical, chemical and biologically contaminants that may affect the health of the populace.
\end{abstract}

Keywords: Metal content; Bacteriological analysis; Borehole water; Abakaliki; Nigeria

\section{Introduction}

Waterborne diseases such as cholera and other forms of diarrhea constitute a major health burden on the economy of any country. And interventions aimed at improving the quality of water inclusive of proper disinfection will significantly improve the health status of the benefitting communities. To ensure continuous availability and supply of drinkable water to the human populace in Nigeria, it is essential to consider the physical, chemical and microbial aspects in the processing and distribution of potable water. Proper water disinfection therefore is paramount to handle any physical, chemical or microbial contamination of water meant for human use. According to Eze and Madumere, ensuring good quality of drinking water is a basic factor for guaranteeing public health, the protection of the environment and sustainable development [1]. Potable water is that which is odourless, colourless, practically tasteless and free from physical, chemical and microbial (biological) contaminants [2]. Water is exploited by man for several commercial, agricultural, domestic and industrial usages. However, the usage of water for domestic and/or human consumption depends on its drinkability (cleanness) since water can serve as route for the transmission of waterborne diseases. The quality of water is determined by its physical, chemical and microbiological characteristics [3]. Water can be described as potable when it meets chemical, physical and microbiological standards. Groundwater sources are commonly vulnerable to pollution, which may degrade their quality; and the quality of groundwater usually varies from place to place, sometimes depending on seasonal changes [4,5] Most people in developing countries resort to groundwater sources such as boreholes as alternative water sources due to lack of access to potable water. Water quality in Nigeria is however, threatened by natural and man-made activities which influences the quality of both surface and ground water. The management of water quality either for domestic or industrial production is thus critical for the effective control and

*Corresponding author: Ejikeugwu Chika, Faculty of Science, Department of Applied Microbiology, Ebonyi State University, P.M.B 102, Abakaliki, Ebonyi State, Nigeria, Tel: +2348097684562; E-mail: ejikeugwu_chika@yahoo.com

Received October 14, 2017; Accepted May 01, 2018; Published May 08, 2018

Citation: Chidinma I, Ifeanyichukwu I, Emmanuel N, Monique A, Chika E (2018) Evaluation of the Metal Content and Bacteriological Parameters of Selected Borehole Water Sources in Abakaliki, Nigeria. Int J Waste Resour 8: 338. doi 10.4172/2252-5211.1000338

Copyright: (c) 2018 Chidinma I, et al. This is an open-access article distributed under the terms of the Creative Commons Attribution License, which permits unrestricted use, distribution, and reproduction in any medium, provided the original author and source are credited. 
management of water pollution as well as waterborne diseases and infection in our communities. Borehole water is a primary source of water in most parts of Nigeria; and the chemical, physical and microbial constituents of these sources of water is a critical public health issue that needs to be ascertained from time to time. According to Agwu et al., borehole water and packaged sachet water serves as the easily accessed and cheap commercial sources of drinking water for a greater number of the Nigerian populace [3]. This study determined the metal content and bacteriological quality of some selected borehole water sources in Abakaliki metropolis, Nigeria.

\section{Materials and Methods}

\section{Study area}

The study area is Abakaliki metropolis where access to potable water is in a pitiable state especially in the surrounding communities of Abakaliki, Ebonyi State, Nigeria. Also, there have been frequent outbreaks of waterborne diseases including cholera in Abakaliki metropolis and some parts of Ebonyi State, Nigeria. Borehole water samples were used in this study because it represents the major source of water supply to many inhabitants of Abakaliki, Nigeria. Ebonyi state is known for its large mineral deposits including limestone and lead which are heavily mined for commercial purposes.

\section{Collection and processing of water samples}

The borehole water samples were aseptically collected using presterilized plastic containers from five major areas located within Abakaliki metropolis, Ebonyi State, Nigeria. A total of 25 water samples (comprising $250 \mathrm{ml}$ each) were collected by first disinfecting and opening the taps and allowing the water rush out for two minutes before collection. The collected water samples were properly labeled and transported within an hour to the Laboratory Unit of Applied Microbiology Department and Industrial Chemistry Department of Ebonyi State University, Abakaliki, for bacteriological and physicochemical analysis respectively.

\section{Bacteria isolation}

The bacteriological analysis of the water samples was done according to the methods of Olajubu and Ogunika; and Obi and George [6,7]. An aliquot of $100 \mathrm{ml}$ each from the collected water samples was filtered through a $0.45 \mu \mathrm{m}$ pore size membrane filter (Milipore, Amesterdam, Netherlands) which was aseptically placed onto MacConkey agar, cysteine lactose electrolyte deficiency (CLED) agar, eosin methylene blue agar (EMB) and mannitol salt agar using a sterile forceps. The culture media plates were incubated aerobically at $37^{\circ} \mathrm{C}$ for $18-24$ hours. The culture media plates were examined macroscopically and microscopically for significant bacterial growth which was identified based on standard microbiological identification techniques [8].

\section{Metal content determination}

The metal content of the borehole water samples analyzed in this study was carried out according to the method described by Mendham et al. using the atomic absorption spectrophotometer (AAS) [AA-7000] [9]. The trace metals detected by the ASS (AA-7000) in this study include zinc $(\mathrm{Zn})$, manganese $(\mathrm{Mn})$, lead $(\mathrm{Pb})$, aluminium $(\mathrm{Al})$ and iron $(\mathrm{Fe})$. Briefly, standard solutions were prepared for each metal using suitable metals of each element to be determined. The AAS was switched on and the required lamp for each metal was fixed. The samples (which were a representative sample from the different collection spots) and the standards of each of the five metals were aspirated simultaneously according to standard analytical procedure; and the absorbance readings produced were measured and recorded according to standard procedures [9].

\section{Statistical analysis}

All data were expressed as means \pm standard deviation, and the results were statistically analysed using the statistical package for social sciences (SPSS) version 23.0. A one-way analysis of variance (ANOVA) and correlation were carried out, and the differences were considered statistically significant if $\mathrm{p}<0.05$ at $95 \%$ confidence level (for ANOVA).

\section{Results}

Table 1 shows the results of the bacteriological analysis carried out on all the water samples analyzed in this study. The highest bacteria count from the water samples was $2.4 \times 10^{4} \mathrm{cfu} / \mathrm{ml}$ while the least bacterial count was $1.0 \times 10^{4}$ (Table 1$)$. The result of the metal analysis of the water samples carried out in this study is shown in Table 2. Further bacteriological analysis of the borehole water samples showed significant traces of the presence of Escherichia coli, Klebsiella species, Staphylococcus aureus and Pseudomonas aeruginosa $(\mathrm{p}<0.05)$.

The results of the trace metals determination showed that the metals in the borehole water samples were within maximum acceptable/ recommended limits for drinking water set by Standard Organization of Nigeria (SON) and World Health Organization (WHO). There was a significant detection of trace metals in the borehole water samples $(\mathrm{p}<0.05)$; and the trace metals detected included zinc $(\mathrm{Zn})$, iron $(\mathrm{Fe})$ and manganese $(\mathrm{Mn})$ - which were all detected at significantly acceptable limits according to the SON and WHO standards. However, aluminum $(\mathrm{Al})$ and lead $(\mathrm{Pb})$ were not detected by the AAS (AA-7000) used in this study. Table 3 shows the standards of the metal content of water meant for public consumption according to WHO and SON standard.

\section{Discussion}

The improvement in the access of people in Nigeria and other developed countries to potable water sources can help to improve the health of the populace. Groundwater such as borehole water represents the world's largest and most important source of potable water to most people in both the rural and urban areas across the world. It is vital to evaluate their physicochemical and bacteriological quality since these sources of water are usually at risk of pollution from human and other environmental or industrial activities. In this study, we evaluated the metal content and bacteriological parameters of some borehole water sources in Abakaliki metropolis in Nigeria. Some bacteria of medical importance including Escherichia coli, Pseudomonas aeruginosa, Klebsiella species and Staphylococcus aureus were significantly isolated $(\mathrm{p}<0.05)$ from the various borehole water samples collected from the different borehole sites in Abakaliki metropolis of Ebonyi State, Nigeria. The highest bacterial count was at $2.4 \times 10^{4} \mathrm{cfu} / \mathrm{ml}$ while the lowest bacterila count was at $1.0 \times 10^{4} \mathrm{cfu} / \mathrm{ml}$. These bacteria are

\begin{tabular}{|c|c|}
\hline Sampling site & Bacteria count (cfu/ml) \\
\hline Site A & $2.4 \times 10^{4}$ \\
\hline Site B & $2.3 \times 10^{4}$ \\
\hline Site C & $2.3 \times 10^{4}$ \\
\hline Site D & $1.0 \times 10^{4}$ \\
\hline Site E & $2.1 \times 10^{4}$ \\
\hline cfu - colony forming unit & \\
\hline
\end{tabular}

Table 1: Profile of bacteria count. 
Citation: Chidinma I, Ifeanyichukwu I, Emmanuel N, Monique A, Chika E (2018) Evaluation of the Metal Content and Bacteriological Parameters of Selected Borehole Water Sources in Abakaliki, Nigeria. Int J Waste Resour 8: 338. doi: 10.4172/2252-5211.1000338

Page 3 of 4

\begin{tabular}{|c|c|c|c|c|c|}
\hline Sample source & $\mathbf{A l}(\mathbf{m g} / \mathbf{l})$ & $\mathbf{P b}(\mathbf{m g} / \mathbf{l})$ & $\mathbf{M n}(\mathbf{m g} / \mathbf{l})$ & $\mathbf{Z n}(\mathbf{m g} / \mathbf{l})$ \\
\hline Site C & $0.00 \pm 0.0$ & $0.00 \pm 0.0$ & $0.1888 \pm 0.001$ & $0.0239 \pm 0.0$ \\
\hline Site B & $0.00 \pm 0.0$ & $0.00 \pm 0.0$ & $0.0236 \pm 0.001$ & $0.0298 \pm 0.0$ \\
\hline Site E & $0.00 \pm 0.0$ & $0.00 \pm 0.0$ & $0.0472 \pm 0.0$ & $0.0179 \pm 0.001$ \\
\hline Site D & $0.00 \pm 0.0$ & $0.00 \pm 0.0$ & $0.00 \pm 0.0$ & $0.0298 \pm 0.0$ \\
\hline Site A & $0.00 \pm 0.0$ & $0.00 \pm 0.0$ & $0.0118 \pm 0.001$ & $0.0179 \pm 0.0$ \\
\hline SON & 0.2 & 0.01 & 0.2 & 3 \\
\hline WHO & $0.1-0.2^{*}$ & 0.01 & - & $0.058 \pm 0.0$ \\
\hline
\end{tabular}

Key: $\mathrm{Al}=$ Aluminium; $\mathrm{Pb}=$ Lead; $M n=$ Manganese; $\mathrm{Zn}=\mathrm{Zinc} ; \mathrm{Fe}=\mathrm{Iron}$

Table 2: Concentration of metals in water samples.

\begin{tabular}{|c|c|c|c|}
\hline S/No. & Parameters & WHO standard (mg/L) & SON Standard (mg/L) \\
\hline 1 & Iron (Fe3+) & 0.3 & 0.3 \\
\hline 2 & Manganese (Mn) & NS & 0.2 \\
\hline 3 & Aluminium & 0.1 & 0.2 \\
\hline 4 & Zinc (Zn) & 15 & 3.0 \\
\hline 5 & Lead (Pb) & 0.01 & 0.01 \\
\hline WHO - World Health Organization, SON - Standard Organization of Nigeria, NS = Not Stated \\
\hline
\end{tabular}

Table 3: Heavy metals acceptable limits according to SON and WHO standard.

of public health importance owing to their implication in a handful of infections and diseases notable in human populace. This report is similar to the study conducted by Agwu et al. and Adekoyeni and Salako who showed that some Gram-positive and Gram-negative bacteria including E. coli and S. aureus are prevalent in borehole water samples in Aba and Ogun state of Nigeria respectively [3,10]. Similar prevalence of bacteria has also been reported by Engwa et al. in Enugu state, Nigeria [2]. The group of bacteria isolated from the borehole water samples bacteriologically analyzed in this study is of immense public health importance because of their implication in a number of diarrheal infections in the human populace $[1,11]$. The result of the atomic absorption spectrophotometer (AAS) used to analyze the borehole water samples showed the presence of some trace metals such as zinc $(\mathrm{Zn})$, iron $(\mathrm{Fe})$ and manganese $(\mathrm{Mn})$. Though the results of the trace metals determination showed that the metals in the borehole water samples were within maximum acceptable/recommended limits for drinking water set by World Health Organization (WHO) and Standard Organization of Nigeria (SON), the bioaccumulation of metals in consumers is a major concern for public health. Aluminium $(\mathrm{Al})$ and lead $(\mathrm{Pb})$ were not detected in any of the borehole water samples. The presence of lead and aluminium in drinkable water samples is a major health risk for consumers. Aluminium may cause some neuro-degenerative disorders while lead $(\mathrm{Pb})$ is a cumulative poison which is believed to be toxic in small concentrations because it can cause lethargy, loss of appetite, constipation, anaemia, abdominal pain, gradual paralysis in the muscles, and/or even death [12-14]. It was also discovered in this study that the concentration of manganese $(\mathrm{Mn})$ in borehole water samples collected at site C $(0.1888 \pm 0.001 \mathrm{mg} / \mathrm{l})$ was close to limits prescribed by SON $(0.2 \mathrm{mg} / \mathrm{l})$. The concentration of zinc $(\mathrm{Zn})$ and iron $(\mathrm{Fe})$ in the water samples analyzed in this study were also found to be within the acceptable limits of SON and WHO. Manganese $(\mathrm{Mn})$ has no health concern at levels found in drinking water, but could causes grey or black stains on porcelain, enamel, and fabrics; and this element could promote growth of certain kinds of bacteria that clog pipes used for water supply [13].

\section{Conclusion}

The bacteriological quality and metal content of some borehole water samples in Abakaliki metropolis, Nigeria were presumptively and successfully carried out in this study. Our study showed significant isolation of some bacteria of medical importance. However, lead $(\mathrm{Pb})$ was not detected in any of the water sample; and this shows that the water sources are good for human use. This study also provides a fundamental background for future and all-round analysis of borehole water samples in this part of the world as a panacea to providing potable water free from physical, chemical and biological contamination to the populace.

\section{Recommendations}

In order to interrupt and begin to reverse the spread of waterborne diseases including cholera and other diarrheal cases in this environment, it is important for the authorities to make potable water available for the populace. We therefore recommend proper environmental impact assessment and assessment of potentia contamination sources before the construction of boreholes for other public water works for human use. Proper disinfection of borehole water samples in this part of the world is also advocated and encouraged as a panacea to nip in the bud the ugly trends of waterborne diseases common in the area.

\section{References}

1. Eze SO, Madumere IC (2012) Physicochemical and Microbiological Analysis of Water Bodies in Uturu, Abia State, Nigeria. Asian J Nat App Sci 1: 58-65.

2. Engwa AG, Tagbo NR, lyala CPJ, Unaegbu M (2015) Physicochemical and Microbial Analysis of Potable Water Sources in Enugu Metropolis. J Pub Health Epidemiol 7: 65-70.

3. Agwu A, Avoaja AG, Kalu AU (2013) The Assessment of Drinking Water Sources in Aba Metropolis, Abia State, Nigeria. Res Environ 3: 72-76.

4. Trivedi P, Bajpai A, Thareja S (2010) Comparative Study of Seasonal Variations in Physico-chemical Characteristics in Drinking Water Quality of Kanpur, India with Reference to 200 MLD Filteration Plant and Groundwater. Nature Sci 8: 11-17

5. Vaishali P, Punita P (2013) Assessment of Seasonal Variations in Water Quality of River Mini, at Sindhrot, Vadodara. Int J Environ Sci 3: 1424-1436.

6. Olajubu FA, Ogunika F (2014) Assessment of the Physico-chemical and Microbiological Properties of Borehole Water Samples from Akungba-Akoko, Ondo State, Nigeria. Int J Pharma Science Res 5: 367-374.

7. Obi CN, George P (2011) The Microbiological and Physico-chemical Analysis of Borehole Waters used by Off-campus Students of Michael Okpara University of Agriculture, Umudike (MOUAU), Abia State, Nigeria. Res J Biological Sci 6: 602-607.

8. Cheesbrough M (2006) Medical Laboratories Manual for Tropical Countries.

9. Mendham J, Denney RC, Barnes JD, Thomas M (2004) Vogel's Textbook of 
Citation: Chidinma I, Ifeanyichukwu I, Emmanuel N, Monique A, Chika E (2018) Evaluation of the Metal Content and Bacteriological Parameters of Selected Borehole Water Sources in Abakaliki, Nigeria. Int J Waste Resour 8: 338. doi: 10.4172/2252-5211.1000338

Page 4 of 4

Quantitative Chemical Analysis (6th edn.). Pearson Education Ltd., India.

10. Adekoyeni O, Salako S (2012) Microbiological, Physicochemical and Mineral Quality of Borehole Water in ljebu Land, Ogun State, Nigeria. Int J Sci Adv Technol 2: 23-30.

11. Madigan MT, Martinko JM, Dunlap PV, Clark DP (2009) Brock Biology of microorganisms (12th edn.). Pearson Benjamin Cummings Publishers, USA. pp: 795-796.
12. Standard Organisation of Nigeria (2007) Nigerian Standard for Drinking Water Quality. Nigerian Industrial Standard NIS 554, Abuja.

13. US Environmental Protection Agency (1994) Water-quality criteria, standards or recommended limits for selected properties and constituents.

14. World Health Organization (2011) Guidelines for Drinking-water Quality. WHO, Geneva. pp: 84-102. 